\title{
Using Joinpoint Regression for the Analysis of Trends in Syphilis Incidence in Poland in the Years 1950-2017
}

\author{
Marcin Milewski ${ }^{1}$, Rafał Milewski ${ }^{2}$, Gabriela Sokołowska ${ }^{3}$, \\ Anna Justyna Milewska ${ }^{4}$
}

1 Scientific Group at Department of Statistics and Medical Informatics, Medical University of Bialystok, Poland

2 Doctoral studies at Faculty of Health Sciences, Medical University of Bialystok, Poland

3 Doctoral studies at Faculty of Medicine, Medical University of Bialystok, Poland

4 Department of Statistics and Medical Informatics, Medical University of Bialystok, Poland

\begin{abstract}
Syphilis is a bacterial sexually transmitted disease (STD), whose main route of infection is through sexual contact. In order to diagnose syphilis, Treponema pallidum must be detected in the material sampled from a lesion and a blood test must be performed in order to detect serological response to syphilis. Since 1946, a statutory obligation to report all cases of syphilis has been in force in Poland, which is why data concerning the incidence is available. The aim of this paper is to analyse trends in syphilis incidence in the years 19502017 using Joinpoint Regression and to present the impact of prophylaxis and education of society on syphilis prevention. The Joinpoint Regression method indicated the splitting time points of the trend corresponding to real changes in incidence, which corroborates the purpose of using the method in question in epidemiological studies.
\end{abstract}

\section{Introduction}

Syphilis (Latin: leus, syphilis) is a bacterial sexually transmitted disease, which it is mainly possible to be infected with through sexual contact. It is caused by a bacterium called Treponema pallidum ssp. Pallidum. Its 'golden years' occurred in the $16^{\text {th }}$ century. It is thought that syphilis appeared in Europe at the end of the $15^{\text {th }}$ century, which was connected with the return of Columbus and his crew from their second voyage to America. Among the native population, syphilis was a common benign disease (Oriel, 1994).

The disease can be divided into two types, according to the presence of symptoms: symptomatic syphilis and latent syphilis. The most recognizable 
symptom of syphilis is a chancre - the primary lesion (affectio primaria) appearing where Treponema pallidum entered the body. The site is usually the mucous membrane or damaged skin within the reproductive organs. The ulceration is usually accompanied by regional lymphadenopathy. It should be remembered that syphilis can remain completely asymptomatic for several years, with the consequences of infection appearing after many years, leading to disability or death (Mroczkowski, 2006).

Nowadays the appearance of the primary lesion can be atypical and should be differentiated with viral infections. This is mainly connected with the widespread use of broad spectrum antibiotics. This may have an impact on the course of the disease, resulting in its atypical clinical presentation.

A special variant of the disease is congenital syphilis. Vertical transmission may result in miscarriage or foetal death, while in the case of live births, the disease manifests itself with a triad of symptoms, i.e. Hutchinson's triad: Hutchinson teeth, labyrinthine deafness, and parenchymatous inflammation of the cornea leading to cataract. The following characteristics of appearance may be typical in a child with congenital syphilis: olympic brow (brow disfigured by periosteum), saddle nose (destruction of the nasal bridge), sabre shanks (protuberances and deformations of the lower leg bones), or Clutton joints (painless enlargement of knee joints) (Lipska \& Konarska, 1999).

Several years following the infection starts the period of late syphilis. During this time, nodular lesions appear on the skin and symptoms develop depending on the affected system. Late syphilis is localized mainly in the nervous and the cardiovascular system. The course of neurosyphilis is mild early on, with headaches, nausea, and neck stiffness. Over the years, mental disorders, speech disorders, and disorientation appear. Another characteristic feature is an increased risk of stroke at an early age. For cardiovascular syphilis, aneurysms are typical, especially in the area of the ascending aorta (Jabłońska, 1973).

In order to diagnose syphilis, Treponema pallidum must be detected in the material sampled from a lesion and a blood test must be performed in order to detect serological response to syphilis. For many centuries, syphilis was practically incurable; the breakthrough was the discovery of penicillin (Niemiec et al., 2008). Nowadays, syphilis treatment is still based on procaine penicillin, administered intramuscularly or intravenously, which ensures Treponema pallidum-killing concentrations in blood at doses of 2.4 million units for 21-28 days (Janier et al., 2015).

In Poland, the obligation to report cases of syphilis was introduced in 1946 by decree of 16 April 1946 on the eradication of venereal diseases (Dekret z dnia 16 kwietnia 1946 r. o zwalczaniu chorób wenerycznych, 1946). 
Doctors' response to this ordinance, however, was insufficient and thus Circular No. 7/48 of 22 January 1948 (no. II 733/48) on the eradication of venereal diseases (Okólnik Nr 7/48 z dnia 22 stycznia 1948 r. (nr. II. 733/48) w sprawie zwalczania chorób wenerycznych) was issued in 1948, which specified the responsibilities of doctors concerning venereal diseases (KempińskaMirosławska \& Woźniak-Kosek, 2013). Currently, the Act of 5 December 2008 on the prevention and eradication of infections and infectious diseases in people (Ustawa z dnia 5 grudnia 2008 r. o zapobieganiu oraz zwalczaniu zakażeń i chorób zakaźnych u ludzi, 2008), which stipulates that a doctor who suspects or diagnoses an infection, infectious disease, or death as a result of infection or infectious disease, specified in the relevant Ordinance of the Minister of Health, is obliged to report this fact to the relevant state sanitary inspector. The report is to be made without delay, but no sooner than within 24 hours of the moment the infection, infectious disease, or death resulting from infection or infectious disease is suspected or diagnosed (Paszkowska, 2019). Epidemiological data collected in this manner makes it possible to analyse trends in incidence over more than 70 years. A significant problem in epidemiological studies is obtaining information that would reflect the real situation. Unfortunately, such data is not always collected in a reliable manner. In Poland, it is collected from sexually transmitted diseases outpatient clinics, which means that the responsibility for reporting does not cover those patients who are treated, e.g., in private practices (Wojtyniak \& Goryński, 2016). Moreover, not all doctors fulfil the statutory obligation to report cases of syphilis (Jenerowicz et al., 2003; Majewski \& Rudnicka, 2013). Another difficulty in analysis is incompleteness of information about incidence divided into the three variants of the disease.

The aim of this paper is to analyse the trends in syphilis incidence in the period 1950-2017 using Joinpoint Regression and to present the impact of education of society on syphilis prevention.

\section{Materials and methods}

The analysis uses syphilis incidence rates (per 100,000 persons) in Poland in the years 1950-2017. The analysed information concerns the incidence of all variants of syphilis combined. The sources for the data were Healthcare Statistical Yearbooks (Gradowski, 1979, 1982; Krzeczkowska, 1969, 1971, 1975) and Statistical Bulletins of the Ministry of Health (Centrum Systemów Informacyjnych Ochrony Zdrowia, 2000, 2001, 2002, 2003, 
2004, 2005, 2006, 2007, 2009, 2010, 2013, 2015, 2017, 2018). Joinpoint Regression software (Version 4.7.0.0. February, 2019) and MS Excel were used for calculations and graphical data presentation.

Incidence analysed over a period of many years is very often characterized by changes in both the pace (fast, slow growth) and direction (increase, decrease) of incidence. For this reason, nonlinear models or, alternatively, Joinpoint Regression need to be used. The method in question consists in fitting several linear (or log-linear) segments to data, that are connected at the time points, where a change in the trend occurs (Joinpoint Help Manual 4.6.0.0, 2018).

In order to create a model that would describe changes in incidence, loglinear model and Annual Percent Change (APC) were used in this paper, the latter of which is a parameter that characterizes the pace of changes in incidence over time. When interpreting this parameter, incidence rates are described as changing at a fixed percentage each year. For example, if the $\mathrm{APC}$ is $1 \%$, and the incidence rate is 50 per 100,000 in 2000, then in 2001 this figure is $50 \times 1.01=50.5$, while in 2002 it is $50.5 \times 1.01=51.005$. If the rates change by a fixed percentage each year, then they are described as changing linearly on a logarithmic scale.

$$
A P C=100 \cdot(\exp (\beta)-1)
$$

The Joinpoint Regression Program was used to fit weighted leastsquares regression models to the incidence rate on the logarithmic scale. It was assumed that the error random variable in the model is homoscedastic. For a Joinpoint software run, a minimum of two observed time points in the beginning and ending line segments (including the joinpoint) and a minimum of two observed timepoints in any middle line segment (including the two joinpoints) were allowed. A minimum of three and a maximum of six joinpoints were searched for using the Grid search algorithm, the permutation test, and the overall alpha level of 0.05. APC is annual percent change (Ingram et al., 2018).

\section{Results and discussion}

At the settings specified above, Joinpoint Regression created models based on 3, 4, 5, and 6 joinpoints, with the 6-joinpont model the best fitted one (Table 1, Figure 1). Table 2 shows individual time periods, for which separate log-linear models were created with the APC parameter describing 
Using Joinpoint Regression for the Analysis of Trends in Syphilis...

Table 1. Selected joinpoints (CI is $95 \%$ confidence interval)

\begin{tabular}{|c|c|c|c|}
\hline & Year & Lower CI & Upper CI \\
\hline Joinpoint 1 & 1954 & 1952 & 1956 \\
\hline Joinpoint 2 & 1964 & 1956 & 1967 \\
\hline Joinpoint 3 & 1969 & 1961 & 1972 \\
\hline Joinpoint 4 & 1976 & 1968 & 1990 \\
\hline Joinpoint 5 & 1998 & 1973 & 2006 \\
\hline Joinpoint 6 & 2007 & 1999 & 2015 \\
\hline
\end{tabular}

Table 2. Final selected model for 6 joinpoints

\begin{tabular}{|c|c|c|c|l|}
\hline $\begin{array}{c}\text { Joinpoint } \\
\text { regression } \\
\text { model line } \\
\text { segments }\end{array}$ & Slope $\beta$ & $A P C$ & $\begin{array}{c}\text { P value of test } \\
\text { that slope }=0\end{array}$ & $\begin{array}{c}\text { P-value of test that slopes } \\
\text { do not differ }\end{array}$ \\
\hline $1950-1954$ & -0.285 & $-24.8^{*}$ & 0.001 & Slope 2 vs Slope $1: p=0.001$ \\
\hline $1954-1964$ & -0.011 & -1.1 & 0.436 & Slope 3 vs Slope $2: p<0.001$ \\
\hline $1964-1969$ & 0.194 & $21.4^{*}$ & $<0.001$ & Slope 4 vs Slope $3: p<0.001$ \\
\hline $1969-1976$ & -0.202 & $-18.3^{*}$ & $<0.001$ & Slope 5 vs Slope $4: p=0.001$ \\
\hline $1976-1998$ & -0.087 & $-8.3^{*}$ & $<0.001$ & Slope 6 vs Slope $5: p=0.004$ \\
\hline $1998-2007$ & -0.027 & -2.7 & 0.107 & Slope 7 vs Slope $6: p<0.001$ \\
\hline $2007-2017$ & 0.052 & $5.3^{*}$ & $<0.001$ & \multicolumn{2}{l}{. } \\
\hline
\end{tabular}

* indicates that the Annual Percent Change (APC) is significantly different from zero at the alpha $=0.05$ level)

the pace of change. The last column of the table below informs whether the trend changes in joinpoints was statistically significant, hence indirectly indicating whether the points were selected appropriately.

It is estimated that after the end of World War II, over $10 \%$ of the population were infected with syphilis. Due to this dramatic situation, many steps aimed at containing it were taken. In 1948 the "W" Action was undertaken, whose aim was to eradicate venereal diseases. Among the undertaken measures were free access to treatment, the creation of a network of serology laboratories, and the establishment of widespread health education as well as establishing the Polish Institute of Sexually Transmitted Diseases in 1949. The effects of these actions were astounding (Koronowska, 2010). In 1950, syphilis incidence was very high. Over 31,000 cases were 


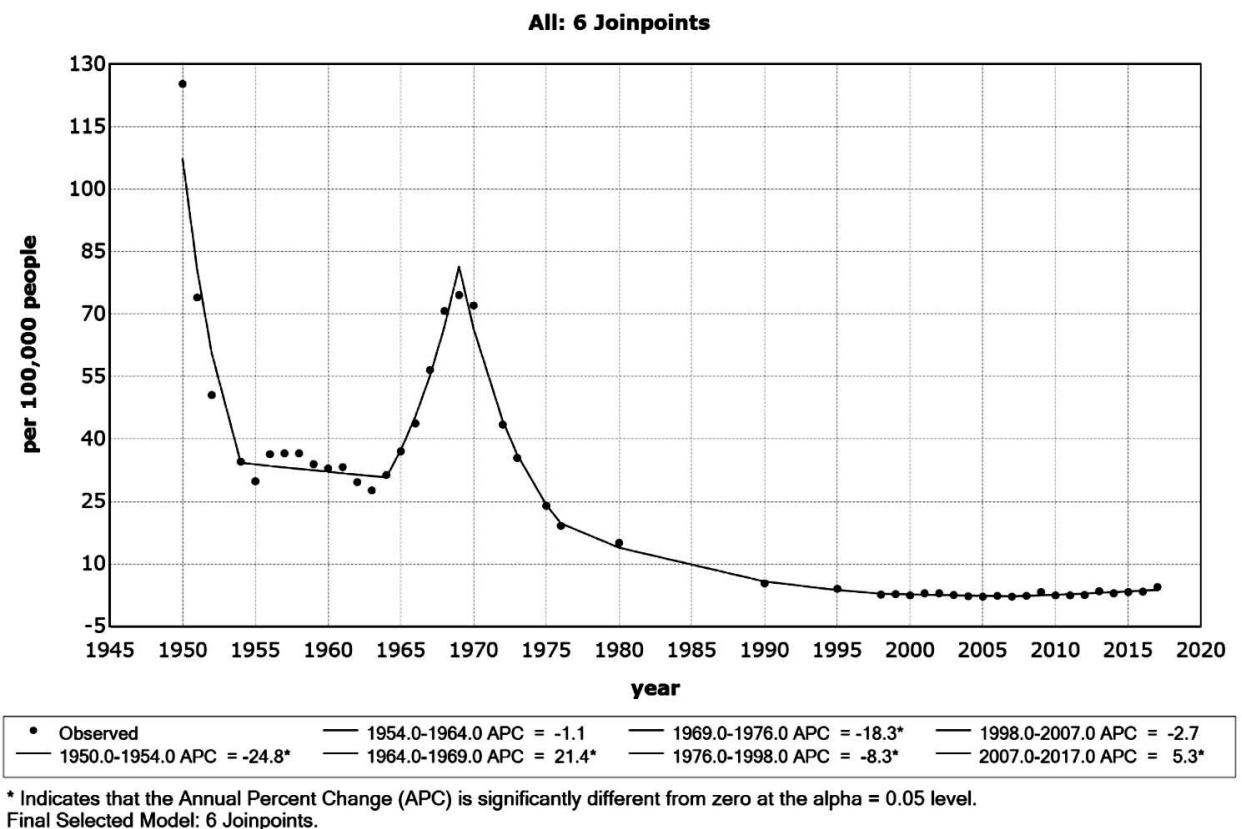

Figure 1. Incidence rates together with a fitted line for the six-joinpoits model

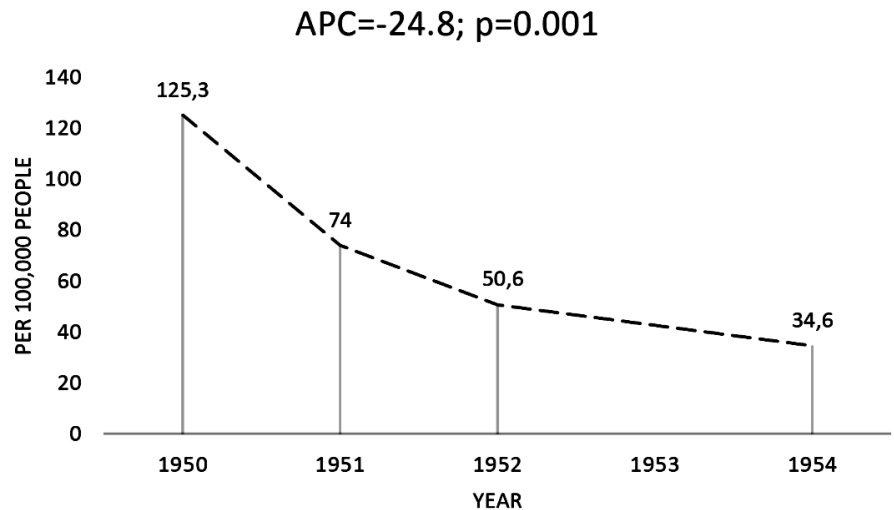

Figure 2. Syphilis incidence rates in the years 1950-1954

recorded, with the incidence rate of 125.3 persons per 100,000 . In the period 1950-1954 (Figure 2), an almost 25\% decrease in incidence per year was noted $(A P C=-24.8 ; p<0.001)$. The incidence rate fell to the level of 34.6 per 100,000 persons. Such a success made it seem that the problem of venereal diseases had been solved, which is why the Institute was closed down in 1957 and many campaigns aimed at prevention were withdrawn (Jabłońska, 1973). 
Using Joinpoint Regression for the Analysis of Trends in Syphilis...

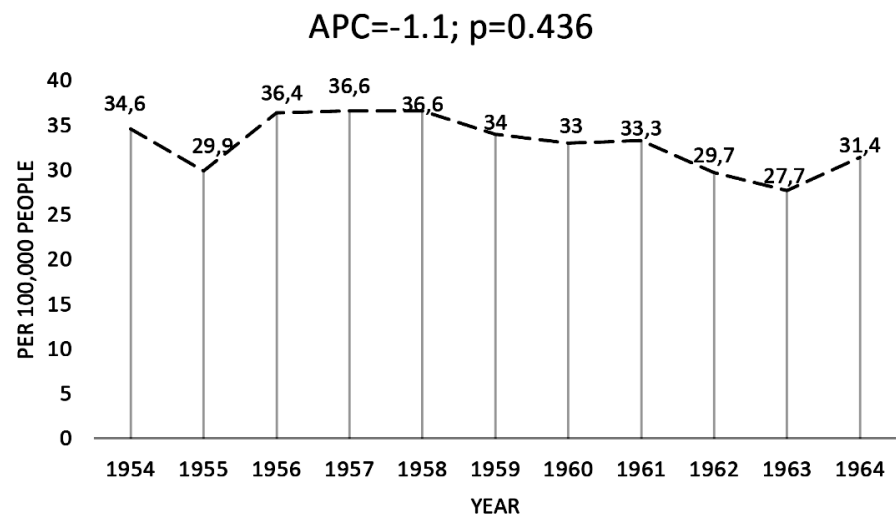

Figure 3. Syphilis incidence rates in the years 1954-1964

For the following 10 years (Figure 3), the incidence rate was relatively constant (a statistically insignificant decrease of $A P C=1 \%, p=0.436$ ).

In 1964, an increase in the number of syphilis cases was observed again. In a period of 5 years (1964-1969), an increase in incidence by over $21 \%$ a year $(A P C=21.4, p<0.001)$ was noted, while the incidence rate increased from a 31.4 to 74.6 per 100,000 (Figure 4). This resulted from the earlier limitations on STD prevention campaigns, with the situation being exacerbated by the start of the hippie revolution (1967), which considered full sexual freedom as one of its main foundations. Only when the Polish Institute of Sexually Transmitted Diseases was reactivated, was it possible to bring the situation under control, with an observed decrease in syphilis cases (Koronowska, 2010). Over the next 7 years (1969-1976), the annual decrease in incidence was over $18 \%(A P C=-18.3, p<0.001)$, as shown in Figure 5.

$A P C=21.4 ; p<0.001$

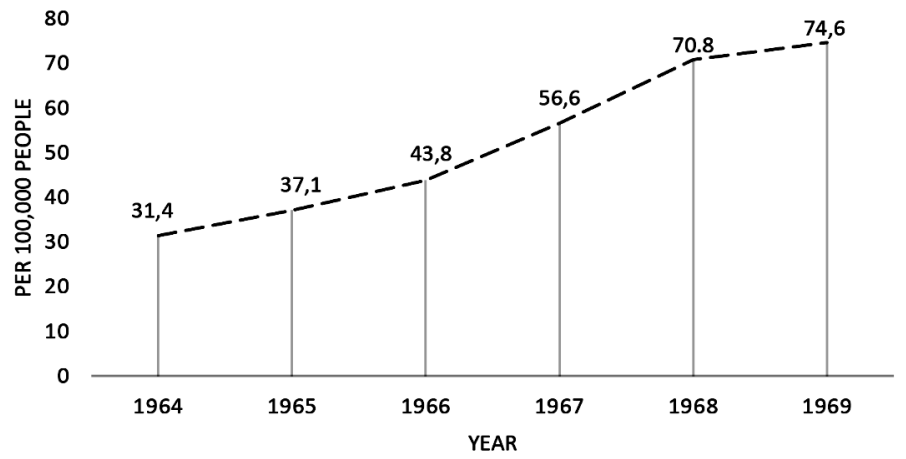

Figure 4. Syphilis incidence rates in the years 1964-1969 
$A P C=-18.3 ; p<0.001$

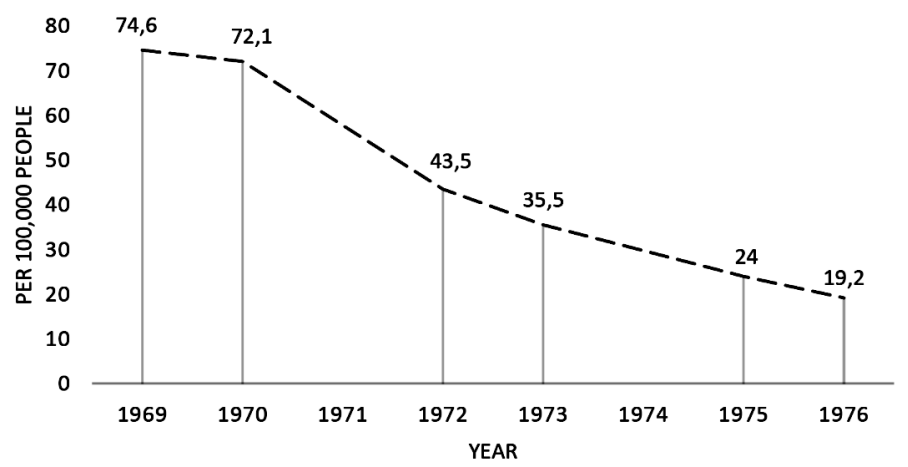

Figure 5. Syphilis incidence rates in the years 1969-1976

Throughout the following years (1976-1998), the constant downward trend continued (Figure 6), it was slightly less pronounced, but still statistically significant, averaging $8 \%$ per year $(A P C=-8.3, p<0.001)$.

\section{$A P C=-8.3 ; p<0.001$}

25

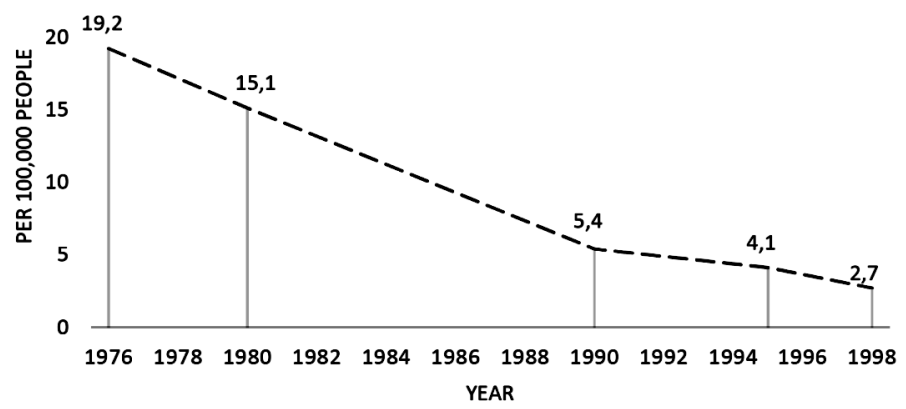

Figure 6. Syphilis incidence rates in the years 1976-1998

In the years 1998-2007 (Figure 7), a further modest decrease in the number of syphilis cases, at a level of almost $3 \%$ a year $(A P C=-2.7$, $p=0.107)$. The change in this level was not statistically significant. The apparently stable level of syphilis incidence might suggest that the epidemiological situation had been contained. It should be remembered, however, that the years in question brought the administrative and healthcare reforms in Poland. Many practices and dermal-STD outpatient clinics were closed down and the system of epidemiological surveillance practically collapsed. Due to the need for finding savings, the number of syphilis screening tests periodically performed in certain professions decreased dramatically. 
Using Joinpoint Regression for the Analysis of Trends in Syphilis...

$A P C=-2.7 ; p=0.107$

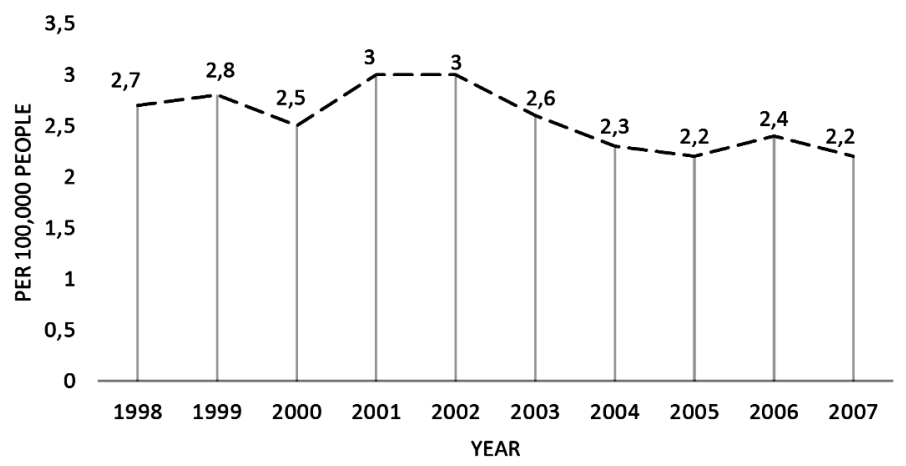

Figure 7. Syphilis incidence rates in the years 1998-2007

This could have had an impact on the reliability of numerical data sourced from the records of sexually transmitted diseases (Jenerowicz et al., 2003; Ministerstwo Zdrowia, 2003).

Despite the apparently high awareness of the modern society, an upward trend in syphilis incidence was observed again since 2007. In the period 2007-2017 (Figure 8), it averaged over 5\% a year, which is a statistically significant increase $(A P C=5.3, p<0.001)$. This trend may result from insufficient funds for prophylaxis and educational activities (Majewski, 2013). In 2017, 1710 persons were infected with syphilis in Poland (Biuletyn Statystyczny Ministerstwa Zdrowia 2018). According to Teter et al. (2019), these results are severely underestimated. His study shows that in the years 2010-2016, the number of syphilis cases in Poland according to NFZ (National Healthcare Fund) data was twice higher than what is indicated by the statistics of the obligatory system of epidemiological surveillance.

$A P C=5.3 ; p<0.001$

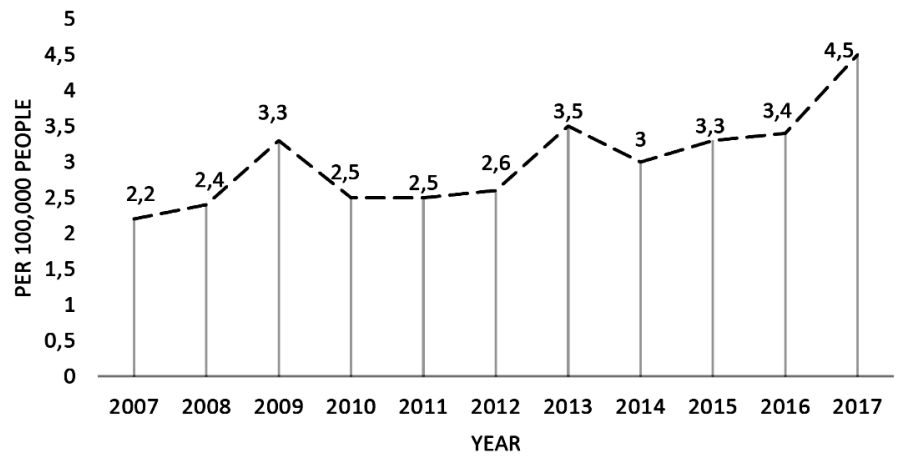

Figure 8. Syphilis incidence rates in the years 2007-2017 


\section{Conclusions}

On the basis of the analysis of trends in syphilis incidence rates in Poland in the years 1950-2017, it can be concluded that the most important decisive factor for the prevalence of the disease in question is the level of prophylaxis and public health education. A decrease in incidence results in reduced vigilance and the conviction that syphilis is an eradicated disease. This leads to more frequent risky sexual contacts and neglect of prophylaxis of congenital syphilis in pregnant women. Paradoxically, this leads to an increase in incidence. Syphilis is a disease that does not pose diagnostic problems. Interpretation of laboratory results in the context of a clinical and epidemiological interview leaves no doubt in terms of establishing a diagnosis. Moreover, treatment is straightforward and publicly available. Currently, although the problem has been greatly reduced, numerous syphilis cases are still recorded. In order to solve the issue, educational activities should be extended and intensified, so that public awareness concerning the pathways of infection, the initial symptoms, and the possibilities of diagnostics and treatment, as well as the possible complications resulting from foregoing treatment. In addition, funds allocated to prevention campaigns should be increased, including those focused on the public availability of free-of-charge and anonymous syphilis tests.

The Joinpoint Regression method indicated the splitting time points of trends that corresponded to real changes in incidence, which corroborates the purpose of using the method in question in epidemiological studies.

\section{R E F E R E N C E S}

Centrum Systemów Informacyjnych Ochrony Zdrowia. (2000). Biuletyn Statystyczny Ministerstwa Zdrowia. Retrieved from https://www.csioz.gov.pl/projekty /statystyka/biuletyn-statystyczny/

Centrum Systemów Informacyjnych Ochrony Zdrowia. (2001). Biuletyn Statystyczny Ministerstwa Zdrowia. Retrieved from https://www.csioz.gov.pl/projekty /statystyka/biuletyn-statystyczny/

Centrum Systemów Informacyjnych Ochrony Zdrowia. (2002). Biuletyn Statystyczny Ministerstwa Zdrowia. Retrieved from https://www.csioz.gov.pl/projekty /statystyka/biuletyn-statystyczny/

Centrum Systemów Informacyjnych Ochrony Zdrowia. (2003). Biuletyn Statystyczny Ministerstwa Zdrowia. Retrieved from https://www.csioz.gov.pl/projekty /statystyka/biuletyn-statystyczny/ 
Centrum Systemów Informacyjnych Ochrony Zdrowia. (2004). Biuletyn Statystyczny Ministerstwa Zdrowia. Retrieved from https://www.csioz.gov.pl/projekty /statystyka/biuletyn-statystyczny/

Centrum Systemów Informacyjnych Ochrony Zdrowia. (2005). Biuletyn Statystyczny Ministerstwa Zdrowia. Retrieved from https://www.csioz.gov.pl/projekty /statystyka/biuletyn-statystyczny/

Centrum Systemów Informacyjnych Ochrony Zdrowia. (2006). Biuletyn Statystyczny Ministerstwa Zdrowia. Retrieved from https://www.csioz.gov.pl/projekty /statystyka/biuletyn-statystyczny/

Centrum Systemów Informacyjnych Ochrony Zdrowia. (2007). Biuletyn Statystyczny Ministerstwa Zdrowia. Retrieved from https://www.csioz.gov.pl/projekty /statystyka/biuletyn-statystyczny/

Centrum Systemów Informacyjnych Ochrony Zdrowia. (2009). Biuletyn Statystyczny Ministerstwa Zdrowia. Retrieved from https://www.csioz.gov.pl/projekty /statystyka/biuletyn-statystyczny/

Centrum Systemów Informacyjnych Ochrony Zdrowia. (2010). Biuletyn Statystyczny Ministerstwa Zdrowia. Retrieved from https://www.csioz.gov.pl/projekty /statystyka/biuletyn-statystyczny/

Centrum Systemów Informacyjnych Ochrony Zdrowia. (2013). Biuletyn Statystyczny Ministerstwa Zdrowia. Retrieved from https://www.csioz.gov.pl/projekty /statystyka/biuletyn-statystyczny/

Centrum Systemów Informacyjnych Ochrony Zdrowia. (2015). Biuletyn Statystyczny Ministerstwa Zdrowia. Retrieved from https://www.csioz.gov.pl/projekty /statystyka/biuletyn-statystyczny/

Centrum Systemów Informacyjnych Ochrony Zdrowia. (2017). Biuletyn Statystyczny Ministerstwa Zdrowia. Retrieved from https://www.csioz.gov.pl/projekty /statystyka/biuletyn-statystyczny/

Centrum Systemów Informacyjnych Ochrony Zdrowia. (2018). Biuletyn Statystyczny Ministerstwa Zdrowia. Retrieved from https://www.csioz.gov.pl/projekty /statystyka/biuletyn-statystyczny/

Dekret z dnia 16 kwietnia 1946 r. o zwalczaniu chorób wenerycznych. (1946). Dz.U. $1946 \mathrm{nr} 18$ poz. 119. Retrieved from http://prawo.sejm.gov.pl/isap.nsf/Doc Details.xsp?id=WDU19460180119

Gradowski, L. (Ed.). (1979). Rocznik Statystyczny Ochrony Zdrowia. 1979. Warszawa: Zarząd Wydawnictw Statystycznych i drukarni.

Gradowski, L. (Ed.). (1982). Rocznik Statystyczny Ochrony Zdrowia. 1981. Warszawa: Zarząd Wydawnictw Statystycznych i drukarni.

Ingram, D. D., Malec, D. J., Makuc, D. M., Kruszon-Moran, D., Gindi, R. M., Albert, M. et al. (2018). National Center for Health Statistics Guidelines for Analysis of Trends. National Center for Health Statistics. Vital and Health Statistics, 2(179), 1-71.

Jabłońska, S. (1973). Osiągnięcia i kierunki rozwojowe dermatologii i wenerologii polskiej. Przeglad dermatologiczny, 30(3a), 116-120. 
Janier, M., Hegyi, V., Dupin, N., Unemo, M., Tiplica, G. S., Potocnik, M., French, P., et al. (2015). Europejskie zalecenia diagnostyczne i lecznicze dotyczace kiły 2014. Przeglad Dermatologiczny, 102, 459-475. doi: https:// doi.org/10.5114/dr.2015.55318

Jenerowicz, D., Pawlaczyk, M., \& Żaba, R. (2003). Kiła ciągłym wyzwaniem dla lekarzy. Przewodnik Lekarza/Guide for GPs, 6(2).

Joinpoint Help Manual 4.6.0.0 (2018). Retrieved from https://surveillance.cancer. gov/help/joinpoint/

Kempińska-Mirosławska, B., \& Woźniak-Kosek, A. (2013). Health policy regarding the fight against veneral diseases in Poland in the years 1945-1958. Military Pharmacy and Medicine, VI(4), 49-72.

Koronowska, S. K. (2010). 430 lat wenerologii polskiej. Nowiny Lekarskie, 79(6), 487-494.

Krzeczkowska, E. (Ed.). (1969). Rocznik Statystyczny Ochrony Zdrowia. 1945-1967. Warszawa: Zarząd Wydawnictw Statystycznych i drukarni.

Krzeczkowska, E. (Ed.). (1971). Rocznik Statystyczny Ochrony Zdrowia. 1971. Warszawa: Zarząd Wydawnictw Statystycznych i drukarni.

Krzeczkowska, E. (Ed.). (1975). Rocznik Statystyczny Ochrony Zdrowia. 1974. Warszawa: Zarząd Wydawnictw Statystycznych i drukarni.

Lipska, E., \& Konarska, Z. (1999). Kiła wrodzona. Nowa Pediatria, 5, 45-49.

Majewski, S., \& Rudnicka, I. (2013). Choroby przenoszone droga płciową w Polsce w 2011 roku. Przeglad Epidemiologiczny, 67(2), 379-381.

Ministerstwo Zdrowia (2003). Narodowy Plan Zdrowotny na lata 2004-2013. Warszawa. Retrieved from http://www2.mz.gov.pl/wwwfiles/ma_struktura/ docs/narodowy_plan_zdrowia_30042004.pdf

Mroczkowski, T. F. (2006). Choroby przenoszone droga ptciowa. Wyd. II poprawione. Lublin: Wydawnictwo Czelej.

Niemiec, K. T., Drews, K., Słomko, Z., \& Pawelczyk, M. (2008). Choroby bakteryjne przenoszone droga płciową. In: Z. Słomko (Eds.), Ginekologia tom 2 (pp. 1003-1008), Warszawa: PZWL.

Oriel, J. D. (1994). The Scars of Venus. A History of Venereology. London: Springer-Verlag.

Paszkowska, M. (2019). Kiła jako choroba zakaźna - aspekty prawne. Wiadomości Lekarskie, $\operatorname{LXXII(9),~cz~II.~}$

Teter, Z., Majkut, G., Wierzba, W., Śliwczyński, A., Brzozowska, M., Jacyna, A., Marczak, et al. (2019). Syphilis in Poland is on the rise and underreported. Adv Dermatol Allergol, 36(2), 192-195. doi: 10.5114/ada.2019.84595

Ustawa z dnia 5 grudnia 2008 r. o zapobieganiu oraz zwalczaniu zakażeń i chorób zakaźnych u ludzi. (2008). Dz.U. 2008 nr 234 poz. 1570. Retrieved from http://prawo.sejm.gov.pl/isap.nsf/DocDetails.xsp?id=WDU20082341570

Wojtyniak, B., \& Goryński, P., (Eds.). (2016). Sytuacja zdrowotna ludności polski i jej uwarunkowania. Narodowy Instytut Zdrowia Publicznego - Państwowy Zakład Higieny. Warszawa. 